\title{
REVIEW
}

\section{Seth Schwartz}

\section{Were the Jews a Mediterranean Society? Reciprocity and Solidarity in Ancient Judaism}

(Princeton and Oxford: Princeton University Press, 2010), hardcover, $x+212$ pp.

Reviewed by Michael J. Cook, Hebrew Union College-Jewish Institute of Religion (Cincinnati campus)

In this erudite and sophisticated volume, Seth Schwartz argues that Jews' social relations in Greco-Roman antiquity were animated by a core tension between Hebrew biblical values and eastern Mediterranean exchange-based reciprocity. He claims that the Jewish biblical corpus (preeminently the Torah) prescribed a radically anti-Mediterranean vision for Israelite society. The Bible assured that the need would rarely arise when people would have to rely on the personal generosity of their neighbors. Therefore, charitable donations would never deteriorate into dependency-generating gifts. Instead, all Israelites should support their fellows, leaving behind some of their harvest, giving the poor a percentage of agricultural production, providing interestfree loans, periodically canceling debts, etc. These would all be done with the intention that not humans but God alone was honored. Reciprocity was thus conceptualized less in terms of relations between humans than between God and Israel.

By contrast, "mediterraneanism" was generated by specifically human relationships such as patronage, vassalage, friendship, debt slavery, social dependency, and euergetism (donations for urban public benefit were reciprocated by displays of honor, loyalty, and memorialization). Schwartz therefore asks how well integrated could the Jews have been in eastern Mediterranean society of the late Seleucid and early Roman periods if their biblical values were ostensibly so strongly opposed to the widely accepted reciprocal-normative system and if institutionalized reciprocity was so very hard to circumvent?

In exploring Jews' abilities to accommodate these tensions, Schwartz applies an ethnographic prism to three corpora of writings seldom used by social and cultural historians: the Wisdom of Ben Sira (180 B.C.E.); late works of Josephus (end of the first century C.E.); and the Jerusalem Talmud (reflecting Jewish life ca. 300 C.E.). Schwartz chooses these texts to demonstrate not an evolutionary development of Jewish stances on these issues but, instead, successive attempts to adapt to altered social and political realities. He concludes that in all these periods many Jews were more deeply involved in eastern Mediterranean bonds of reciprocity and honor than we might ordinarily expect given the Torah's utopian anti-reciprocity orientation.

In Schwartz's analysis, Ben Sira pessimistically views human obsession with gift exchange, institutionalized reciprocity, and honor. However, he also insists that only the wise (i.e., the pious Torah-observant Jews) can best navigate and manage these evils. Josephus in his Jewish Antiquities and Against Apion allows that Jews in some locales absorbed the reciprocity-based norms typical of Greco-Roman cities. Nonetheless, he claims that Jews in Jerusalem remained starkly opposed to these norms, subordinating politics, commerce, and benefaction to the demands of biblical piety. By the time of the Jerusalem Talmud, Schwartz argues that most Jews 
had completely internalized Roman norms, even though rabbis generally preached resistance to these practices.

Full, indeed magnificently rich definitions are offered for each of the technical terms Schwartz regularly employs ("euergetism," "honor," "benefaction," "memorialization," etc.). However, for the most part these extended definitions surface in the book somewhat sporadically and usually belatedly; often the fullest explications are delayed. This problem may send readers scurrying to the well-done index to locate where the fullest definition may be found. Since the needed definitions surface in due course anyway, these rewarding paragraphs might have been more productively shifted earlier for handier access to a detailed, glossary-like opening chapter.

Schwartz anticipates that some readers will be uncomfortable with his operating on too high a level of abstraction, given his use of technical, sometimes theoretical sociological categories. However, the clarity of his writing greatly helps the reader to understand his argumentation despite some lingering ambiguities. At the most basic level, Schwartz's argument would be strengthened by clarification as to whether the Torah's anti-reciprocity stance was a deliberately intended opposition (i.e., ab initio) to Mediterranean norms or merely exerted this impact inadvertently.

Further, granted that Schwartz wishes to concentrate on three later sources from the GrecoRoman period, some readers may nonetheless sense a disorienting chronological disjunction, or a lack of a tight-enough "fit," between the earlier time-frame of most biblical writings and the later era which is Schwartz's central focus. Ben Sira, Josephus, and the Palestinian rabbis were addressing contemporaneous practices and tendencies, but most biblical texts (above all the Torah) antedated by far the time-period Schwartz addresses. For such readers, Schwartz has not sufficiently demonstrated that the mediterraneanism that Ben Sira deplored was altogether consistent with-i.e., that it had maintained itself in a tight-constant configuration from-the earlier days, when the Torah and most other biblical works were being composed and consolidated. For Schwartz to apply biblical dicta to later times requires a fuller demonstration that the Bible was viewed as prescriptive for, and actually adhered to by, Jews in eras long post-dating biblical materials. A strategic means of bridging this chronological disjunction would have entailed a deeper, wider, more detailed demonstration of the degree of abiding adherence by Jews to the biblical mindset over the centuries preceding and leading up to Ben Sira's day.

To be sure, Schwartz does wrestle with the spectrum of contrasting viewpoints on some of these complex chronological issues and earnestly attempts to work through them. That he does so to some extent suggests that he could have done the same but more so in order that Ben Sira not seem to enter the stage in medias res to the extent he does. This would have aided readers to solidify their bearings before Schwartz moves to the later texts.

Schwartz's analyses of Ben Sira and the Jerusalem Talmud are extraordinarily engrossing and compelling. As for Josephus, Schwartz admits that Josephus's motives differ between his earlier work The Jewish War and his later works Jewish Antiquities and Against Apion. Schwartz also recognizes Josephus's proclivity for exaggeration. Yet Schwartz raises surprisingly few doubts about the credibility of Josephus's insistence that Jerusalem's Jews rejected Greco-Roman reciprocal norms. In this, he is influenced by the dearth of archaeological evidence that might challenge this conclusion.

We are indebted to Schwartz for his Herculean triumph analyzing themes and parts of texts hitherto largely ignored. He has dared to traverse dense, unlit fields, enabling us to discern, even if through a glass darkly, the rough contours of what was previously unseen or overlooked. 
Readers of this volume will never again study Ben Sira, Josephus, and the Jerusalem Talmud without benefiting from Schwartz's insights. His comprehensive exploration of Jewish social integration into the eastern Greco-Roman world is thus most strongly welcomed as indispensable for all future research. 